\title{
DISTRIBUTION ANALYSIS OF AVES SPECIES FOR BIODIVERSITY MEASUREMENT IN FOREST AREAS UNAND PADANG
}

\author{
Elvi Zuriyani \\ Program Studi Pendidikan Geografi STKIP PGRI Sumatera Barat \\ pephy27@gmail.com
}

\begin{abstract}
Aves species is very abundant in the forest area of Indonesia and its biodiversity is influenced by a number of environmental quality parameters. This research aimed to determine the level of species diversity and abundance of aves species in forest areas of Padang, West Sumatra, Indonesia. The second purpose of this study was to determine factors affecting of diversity and abundance of aves species. The method of this research used bird survey technique (method list of 20 species of birds). This method can be used to complete the list of bird species was found in the forest area, using the quantity of bird species that have been observed. To restrict it, we can use 20 species of aves. Based on this study, in the forest area of UNAND have 21 species of aves. Based on the relative abundance of bird species, the birds most commonly found are species of wallet. Whereas some other aves species have a relative abundance slightly. This happens because of disruption of habitat for aves and forests area by human activities.
\end{abstract}

Keywords : distribution, aves species, measuring of biodiversity

\section{INTRODUCTION}

Indonesia has the greatest biodiversity in the world. Indonesia's biodiversity is scattered in various places throughout the Indonesian archipelago. Species of birds (Aves) is one of the species whose existence is abundant in Indonesia. Based on the diversity, Indonesia is a country with a diversity of bird species in the world's third richest. Up to now, over 1040 bird species found in Indonesia, 381 types of which are endemic, and 104 species are categorized as endangered species.

Sumatra island has a high biodiversity with extinction rates are relatively high. Total of bird species found on the Sumatra island, are 582 species, of which about 465 are settled and 14 are endemic, making it the second richest biogeographic regions in Indonesia in terms of birds, after Papua. According to BirdLife International, there are 34 Areas Important Bird (Important Bird Areas / IBA) on the Sumatra island, 54\% of which is outside the area projected, and $18 \%$ are in the lowland forest was critically endangered (Critical Ecosistem Partnership Fund, 2001).

Species of birds (aves) is one species that has had an established classification system. Regional distribution of the types of birds that exist in the world today has been relatively complete. Until now, more than 9000 species of birds have been identified in the world. This causes the bird very well serve as an indicator of environmental quality in an area.

Various parameters of the birds (aves) can be used as an indicator of environmental quality, such as the comparison of diversity, diversity index, as well as the presence of certain bird species which plays a special role in the ecosystem. That's why the measurement of the abundance of bird species diversity sector in a region or an area will indicate the quality of the environment. Whether that environment is still natural and preserved or the environment has been damaged as a result of human activities. This research aimed to this research aims to analyze the species diversity and abundance levels of bird species found in forest areas 
UNAND. The second purpose of this study was analyzed the factors that influence the diversity and abundance of bird species.

\section{METHODOLOGY}

This study was conducted in forest area of Andalas University (UNAND) Padang in the morning and afternoon, with sunny weather conditions. The method of this research is using technique of bird survey (method list of 20 species of birds). Observations using the Handbook Field Introduction to Birds in Sumatra, Java, Bali and Kalimantan by Mac.Kinnon (1998). This method can be used to complete the list of bird species was found in the forest area, using the quantity of bird species have been observed. To restrict it, we can use 20 species of birds (aves). There are 4 steps in this observations as follows:

1. Clothing used by observers.

Used clothing with colors that are not flashy

2. Time to observers

Bird activity should be done in the morning and evening, the weather conditions were sunny.

3. Calibration of binoculars

Before using a binoculars we have to calibrate it first with eye conditions

4. Creating sketch of birds

Sketching a birds very helpful in the process of identification. Sketching of birds refers to basics of bird topography, such as the type of beak, tail, claws and wings.

In addition to the four steps above, this reaserch using technique of bird survey (method list of 20 species of birds). This method can be used to complete the list of bird species were found in the forest area, using the number of bird species observed (20 species) as a limitation. After recording 20 species of bird firs are found, the recording is done on the new list, while noting the type that has been recorded in the previous list. With this method can be made invention curve bird species, and relative abundance index can be calculated based on the number of species of the birds. With this method can complete the list of bird species in a region with data on relative abundance indices, and describe the discovery curve types. In addition, also known abundance comparative data types and species diversity index in area of forest.

\section{DISCUSSION}

\section{Relative Abundance value of Bird}

Based on observations of the bird species in the forest area UNAND, found 21 species of birds. This summation of birds obtained by calculation (tally) obtained from the list of species of birds which consists of four lists. The first list is filled during our journey from the faculty of biology to the garden biology, Faterna farm, herb garden and back to faculty of biology. For more details can be seen on the following table.

Table 1. Calculation Value Relative Abundance Birds

\begin{tabular}{|c|c|c|}
\hline \multicolumn{2}{|c|}{ Location : forest area UNAND Total Listing Type of birds : 4} \\
\hline Name types of birds & $\begin{array}{c}\text { Recording in } \\
\text { the list types }\end{array}$ & $\begin{array}{c}\text { Abundance of } \\
\text { relativity }\end{array}$ \\
\hline 1.Colocalia esculenta & 62 & 0.418 \\
2.Dicaeum trigonostigma & 9 & 0.060 \\
\hline
\end{tabular}




\begin{tabular}{|l|c|c|}
\hline 3.Loncura punculata & 23 & 0.155 \\
4.Pacer montana & 3 & 0.020 \\
5.Picnonotus goiavier/berabah & 14 & 0.094 \\
6.Prinia familiaris & 4 & 0.027 \\
7.Treron sp & 7 & 0.047 \\
8.Hemiprocni longipenis & 8 & 0.054 \\
9.Loncura maja & 1 & 0.006 \\
10.Trikayun & 1 & 0.006 \\
11. Picnonotus Bruneus (Berebah merah) & 1 & 0.006 \\
12.Streptopelia chinensis & 1 & 0.006 \\
13.Cocomantic & 1 & 0.006 \\
14.Geopelia striata & 1 & 0.006 \\
15.Halycon smyrnensis & 2 & 0.013 \\
16.Picnonotus Aurigaster (Kutilang) & 4 & 0.027 \\
17.Aeithina tiphia & 1 & 0.006 \\
18.Megalaima hematephalus & 2 & 0.013 \\
19.Dicaeum everttii & 1 & 0.006 \\
20.Megalaima mesofalus & 1 & 0.006 \\
21. Turnik & 1 & 0.006 \\
\hline
\end{tabular}

To see the bird species found in this observations, then made a list of bird species curve consists of 4 list. Based on a list of 1 to 4 have been made, it was concluded that the bird species most often found along the way is a kind of Colocalia esculenta or in a regional language was called wallet birds. Distributions of wallet bird's area is in Java, Sumatra, Kalimantan, Sulawesi, etc. (Dewi, S.T., 2005.). Wallet birds found along the journey in Biology Farrm areas to Faterna Farm areas. wallet birds are the most numerous birds listed in the list of bird species because it can live anywhere, were commonly found almost at various places in rural and urban areas. wallet live in groups, pairs or individually. wallet chose nesting on buildings, under bridges and other places. Because type of Colocalia esculenta or wallet a kind of majority, then the value of relative abundance is also larger than the other, which is equal to 0.418 , which means that the abundance of birds around campus UNAND wallet is the highest. This indicates that type of habitat of wallet is still there or not yet damaged. In the table below will be presented 4 curves list of bird species

Table 2. Curve of Bird Type

\begin{tabular}{|c|c|c|}
\hline & List-1 & List-2 \\
\hline & $\begin{array}{l}\text { Colocalia esculenta } \\
\text { Dicaeum trigonostigma } \\
\text { Loncura punculata } \\
\text { Pacer montana } \\
\text { Picnonotus Aurigaster } \\
\text { Prinia familiaris } \\
\text { Treron sp } \\
\text { Hemiprocni longipenis } \\
\text { Loncura maja } \\
\text { Trikayun }\end{array}$ & $\begin{array}{l}\text { Colocalia esculenta } \\
\text { Loncura punculata } \\
\text { Dicaeum trigonostigma } \\
\text { Turnix } \\
\text { Treron sp } \\
\text { Picnonotus goiavier (Berebah) } \\
\text { Streptopelia chinensis } \\
\text { Cocomantic sepulchralis (wik-wik), } \\
\text { Geopelia striata } \\
\text { Hemiprocni longipenis }\end{array}$ \\
\hline $\begin{array}{l}\text { Number of New } \\
\text { Types }\end{array}$ & $\begin{array}{l}10 \\
10\end{array}$ & $\begin{array}{c}5 \\
15\end{array}$ \\
\hline
\end{tabular}




\begin{tabular}{|l|l|l|}
\hline $\begin{array}{l}\text { The cumulative } \\
\text { number of type }\end{array}$ & & \\
\hline
\end{tabular}

\begin{tabular}{|c|c|c|}
\hline & List-3 & List-4 \\
\hline & $\begin{array}{l}\text { Halycon smyrnensis } \\
\text { Dicaeum trigonostigma } \\
\text { Colocalia esculenta } \\
\text { Loncura maja } \\
\text { Picnonotus Aurigaster } \\
\text { Hemiprocni longipenis } \\
\text { Prinia familiaris } \\
\text { Loncura punculata } \\
\text { Treron sp } \\
\text { Picnonotus } \\
\text { (Kutilang) }\end{array}$ & $\begin{array}{l}\text { Treron sp } \\
\text { Dicaeum trigonostigma } \\
\text { Colocalia esculenta } \\
\text { Hemiprocni longipenis } \\
\text { Aeithina tiphia } \\
\text { Prinia familiaris } \\
\text { Megalaima hematephalus } \\
\text { Dicaeum everttii } \\
\text { Megalaima mesofalus } \\
\text { Loncura punculata }\end{array}$ \\
\hline $\begin{array}{l}\text { Number of New } \\
\text { Types } \\
\text { The cumulative } \\
\text { number of type }\end{array}$ & $\begin{array}{c}2 \\
17\end{array}$ & $\begin{array}{c}4 \\
21\end{array}$ \\
\hline
\end{tabular}

The second type of birds is the most common is Lonchura punctulata also called is peking. The second type is the most common type of Lonchura punctulata also called peking. This bird is commonly found in rural areas, in yards, gardens, forests and fields. In urban areas these birds are in the trees-trees in the garden, on the edge of the road, etc. Distribution of this peking types were commonly in Java, Sumatra, Kalimantan and Sulawesi (Dewi, S.T., 2005.)

Furthermore, the relative abundance of bird species found on the third place is Picnonotus goiavier or berabah. This type were commonly habitats in rural areas, on the lawn, garden, echoes, field and forest, especially in open areas. They live in groups or pairs. Distribution area of this types of birds is Java, Sumatra and Kalimantan. Dicaeum trigonostigma is a birds species that have the highest relative abundance of number 4 . These birds are found in rural areas, yards, gardens, and urban areas in parks or trees along the main road.

Hemiprocni longipenis is a type that has a relative abundance of 0.054 which is the largest bird species to 5 in the list of bird species. Furthermore Threron, Picnonotus aurigaster (Kutilang), Prinia familiaris (Cinenenen), Pacer Montana (burung gereja), Halycon smyrnensis (raja udang), Megalaima hematephalus (Ungkut-ungkut) is a type of bird habitats are generally located in rural areas, yards, gardens and forests. The abundance of bird species that tend to be slightly less than 0.05 .

Areal distribution of these birds are Sumatra and Java. Type this bird is a bird that generally have unique features such as the shape of the body and voice are unique, so this type are widely hunted by bird enthusiasts, such as the type of Picnonotus aurigaster (Kutilang), Halycon smyrnensis (kingfisher), Megalaima hematephalus (Ungkut-ungkut). Furthermore, based on the calculation of relative abundance, the kind of Loncura maja (Gondol Peking), Trikayun, red Berebah , Streptopelia chinensis (Tekukur), Cocomantic sepulchralis (wik-wik), Geopelia striata (turtledove), Aeithina tiphia (Tipo / Turmeric small), Dicaeum everttii (burung cabe), Megalaima mesofalus, and Turnik has a relative abundance of as many as 0,006 . Generally, the types of birds living in rural areas, in fields, in the gardens and woods. These birds generally live in groups, pairs and some even 
alone. Type Cocomantic sepulchralis (wik-wik) is a species of bird that is rather difficult to be seen.

Relative abundance is the value of the number of listings by species divided by the entire list of types and then multiplied by $100 \%$. This relative abundance value is the value that indicates the magnitude of the abundance of bird species in a region, which this time is the campus area of UNAND still prevalent forest plants. However, this area has been used by humans, so in some areas have been established campus buildings. There are also land cleared for roads, building stalls, home and there is land that has been opened and is planned to be built, but until now still dormant construction so that the area becomes the terrain, so the abundance berung-berung are more less.

The other type is the type of Loncura maja (Gondol Peking/finch), is a type of bird that are usually abundant in the area of rice fields, orchards, forests, yards. But at this observation of this kind were not found. It can be caused by Bird preferably focus on those types of unique or error caused by the introduction/calculation birds or indeed natural factors and humans factor make this type more difficult to find.

Based on the list of bird type and amount of cumulative, (at list 1 to list 4), an increase in the number of birds from a single point of observation line to the point of observation to the second line is more increasing. This indicates that more into the forest (about biological garden, and farm faterna) then forest plants/trees and grass more growing. In the open place, the bird rarely found. This occurs because the open area has many of human activity, a decrease in their lives and lead them away from the place (as disturbed). This has resulted in is getting a bit species of birds are found.

Based on observations made from the beginning of the trip, which first start from campus area of biology to the forest areas of biology, it can be found to increase the number and species of birds are found.

In the table 3, showed the List type and cumulative of birds amount.

Table 3. List type and Cumulative of Birds Amount

\begin{tabular}{|c|c|}
\hline Listing Type of Birds & Cumulative of Amount Type of birds \\
\hline 1. & 10 \\
2. & 15 \\
3. & 17 \\
4. & 21 \\
\hline
\end{tabular}

Graph of relations of Type list Birds with Total Cumulative type of birds

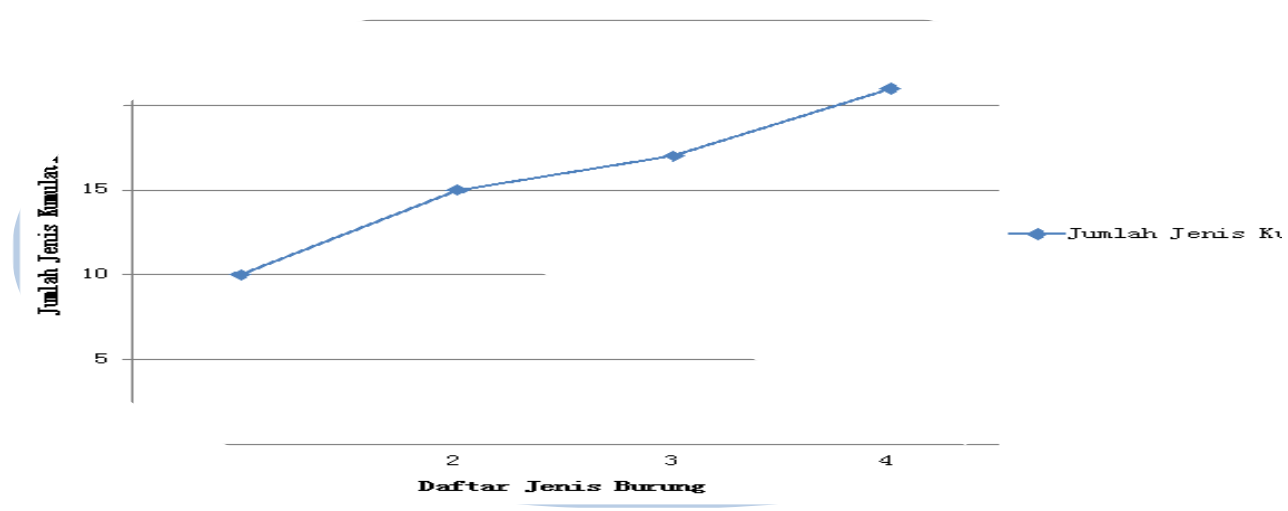


If the habitat of a living being disturbed, it will be lead to the extinction of species of animals and plants that would damage the ecosystem. Increasingly large number of species, the greater the biodiversity. However, through the continuous evolution happens there will be too extinction. When a new species extinction occurred over much of the biodiversity will increase. Conversely, if extinction happens more than the creation of new types of biodiversity will decrease. Likewise with fewer types of biological diversity, the environmental balance will be more easily distracted. Conversely the diverse biodiversity it will be more stable order that environment. Because of that biodiversity is essential, not only for the survival of creatures but also for the preservation of environmental order itself. In the last decade of the 20th century, the rate of biodiversity loss as a rough estimate covers 40 to 400 times the normal extinction rate caused by poaching, destruction of a live animal or plant, pollution is generally caused by human activities.

So are with the presence of various species of birds found in the campus area UNAND. Before was established college buildings and roads, certainly an abundance of bird species found there will be more. However, human activity would further reduce the abundance of bird species are available. That's why the extinction and ecosystem destruction should not be allowed to happen. With preservation of species diversity, essential ecological processes in the ecosystem of life will be maintained as well.

The preservation forest ecosystem as a habitat for many species of birds will not only protect birds but also protects essential ecological processes. It is therefore necessary awareness of the various parties in order to preserve protected areas, in this case in order to maintain the habitat for many species of birds in maintaining biodiversity bird species found in Sumatra region and generally in Indonesia.

\section{CONCLUSIONS}

Based on this observation of the different types of birds in the area of campus UNAND, it is obtained 21 species of birds. Most species of bird is kind of wallet birds.

Value of relative abundance of bird species most commonly found are species of wallet birds. Some other birds were found to have less relative abundance. It is caused by several things such as the disruption of the bird's habitat as well as human activities that lead to species of birds homeless.

Forest as a habitat for various species of birds should have to be kept so that the biodiversity of bird species can be continue to be sustainable.

\section{REFERENCE}


Critical Ecosistem Partnership Fund. 2001. Biodiversity. Worldbank

Dewi, S.T. 2005. Kajian Keanekaragaman Jenis Burung di Berbagai Tipe Landskap Hutan Tanaman Pinus (Studi Kasus: DAS Ciliwung Hulu). Skripsi. Departemen Konservasi Hutan dan Ekowisata Fakultas Kehutanan IPB. Bogor.

MacKinnon. 1998. Buku Panduan Lapangan Pengenalan Burung di Sumatera, Jawa, Bali dan Kalimantan . Gadjah Mada University Press. Yogyakarta.

Odum. 1993. Dasar-dasar Ekologi. Gadjah Mada University Press. Yogyakarta.

Primack, R.B.; Supriatna; Indrawan dan Kramadibrata. 1998. Biologi Konservasi. Yayasan Obor Indonesia. Jakarta

Zoer'aini, Djamal Irwan. 1997. Tantangan Lingkungan dan Landskap Hutan Kota, CIDES. Jakarta. 